JOHN F, KENNEDY-INSTITUT

FÜR NORDAMERIKASTUDIEN

Abteilung für Kultur

WORKING PAPER NO, 32/1991

WINFRIED FLUCK

The Power and Failure of Representation in Harriet Beecher Stowe's Uncle Tom's Cabin. (Inaugural Lecture) 
Copyright (1991 by Winfried Fluck

John F. Kennedy-Institut

für Nordamerikastudien

Freie Universität Berlin

Lansstrasse 5-9

1000 Berlin 33

Germany 


\title{
THE POWER AND FAILURE OF REPRESENTATION \\ IN HARRIET BEECHER STOWE'S \\ UNCLE TOM'S CABIN
}

\author{
by \\ Winfried Fluck
}

I.

Reacting against a long history of neglect, current revisionist studies of American literature have drawn our attention to Harriet Beecher Stowe's Uncle Tom's Cabin as an especially rich and powerful example of sentimentality in the novel. 1 Such attempts to make sense of materials which critics drawing on formalist and modernist models of the . literary text are no longer able to read, redress a long-standing imbalance in American literary history. As is well known, American literary history has almost always been uneasy with Uncle Tom's Cabin, as it has been with sentimentality in general. On the one hand, no critic can completely ignore the fact that Uncle Tom's Cabin is "probably the most influential book ever written by an American." 2 On the other hand, the explicit or implicit aesthetic criteria governing literary histories in the period of high modernism do not provide for a principle 
according to which the novel could be discussed in any meaningful way. J. W. Ward has put the case so well that his characterization of the ensuing dilemma deserves another quotation: "For the literary critic, the problem is simply how a book so seemingly artless, so lacking in apparent literary talent, was not only an immediate success but has endured." 3 One solution to this problem has been to acknowledge the novel, somewhat grudgingly, as an important cultural and political event, whose deplorable aesthetic strategies might be excused for once, since they served a good purpose after all--namely that of mobilizing the American public against slavery. In this way, cultural and aesthetic functions are separated, as if they were not inevitably linked in the emergence and formation of meaning. In contrast, one of the purposes of the new revisionism and historicism in the study of American literature is to bridge this gap between a culturally oriented and an aesthetically oriented reading of fictional texts in order to permit an understanding of sentimentality as both a cultural and an aesthetic strategy.

In the following interpretation I want to draw on some of the results of these new readings of Uncle Tom's Cabin, and I shall then try to supplement and extend them. For it still seems that in talking about the sentimental in literature there is an apparently unavoidable tendency to be stuck with one of two choices: either to criticize sentimental fiction as a text that fails, or to explain and 
defend it by recovering its former cultural function. The two approaches, although strikingly different in emphasis, remain surprisingly similar in structure: both remain within a dichotomous mode of argumentation and cannot acknowledge any interplay between weaknesses and strengths. Thus, while in the first case the critic will be almost exclusively interested in the text's failures, in the second, the goal must be to secure the consistency of an assumed inner cultural and aesthetic logic of the sentimental text--an approach that, useful as it is, is often in danger of a gesture of mere inversion, because it assumes that to point out the potential cultural function of a literary text can also serve as an explanation of aesthetic effect.

As discussions of the problem have indicated again and again, however, the phenomenon of the sentimental in literature may be more complex than a primarily dichotomous model of argumentation suggests. Instead of opting for either the party of failure or for that of success, it seems more helpful and productive to me to relate these opposing perspectives with one another and to bring them thus into a dialogue. 4 It will be my assumption in the following discussion that the two views sketched out are not necessarily mutually exclusive--for to assume so would also mean to assume that the other side is simply ignorant or blind. Rather, they can be seen to highlight different aspects of the same phenomenon--aspects which should both be taken into account and negotiated in one comprehensive 
reading. The task, in this case, would be to do both: to make an attempt to understand the inner working principles and cultural logic of sentimental fiction, and yet to account also for a modern feeling of discrepancy, excess and exaggeration in parts of the novel that seems to be widespread. 5

For such a deliberately interactionist approach it is indispensable to keep the major possibilities of defining the sentimental in literature in mind, instead of opting for any single definition. This seems especially pertinent, since the concept of sentimentality, through its long and varied history, has assumed such a high degree of instability that, along with the word realism, it has almost become a 'floating signifier' which no single definition can hope to tie down and anchor. Still, it seems useful to outline the three major approaches which definitions of the sentimental take:

1) The definition of sentimentality in literature in philosophical or cultural terms, that is, as a new epistemology or a system of cultural beliefs which developed in the eighteenth century and played an important role in American culture of the nineteenth century:

2) The definition of sentimentality in literature in terms of genre, that is, in terms of certain dominant narrative patterns, established, in essence, by 
Richardson and the sentimental novel of the eighteenth century;

3) The definition of sentimentality in fiction in a more narrowly formal and aesthetic sense, as a rhetorical strategy, or, as one might also say, as a mode of representation marked by gestures of rhetorical excess and exaggeration--an aspect of the text which, in contrast to the culture of sentimentality and the sentimental narrative, one could call sentimental rhetoric. 6

I I .

It has been one strategy of those literary and cultural critics who have retained an interest in Uncle Tom's Cabin even in the era of high modernism to emphasize the unusual scope and depth of its social analysis. In its attempt to present the slavery issue in all of its various forms and manifestations, the novel covers a wide range of social life, not only of the American South, but, where necessary, even beyond.

The depth of the novel's social analysis is most apparent in its deliberate attempts to provide a comprehensive picture of how slavery affects the American South: After being exposed first to the still patriarchal and relatively mild forms of slavery that prevail in the gentry household of the Shelbys in Kentucky, we are then taken further South, first to the aristocratic plantation of 
the st. Clares with its alternating rhythm of fastidiousness and cruel neglect; until finally, in a further geographical and moral descent, we have to witness the debased forms of merciless exploitation and physical torture which prevail in the swamp land of Louisiana. In order to avoid the possibility that her case against slavery would be reduced to a discussion of particular instances and environments, Beecher Stowe obviously aimed at a fictional representation of slavery in its totality--which also meant to introduce elements of social and cultural differentiation between the various regional and social segments of the American South. On the other hand, it is quite obvious that such sociological and realistic tendencies remain under the firm control of an unswerving moral perspective. Had sociological explanation and differentiation been carried too far, this would have invited the kind of rationalization and moral relativism with which the males of the novel, even such men of undeniable integrity as Shelby and St. Clare, manage to arrange themselves with the moral scandal of slavery. In order to counter similar rationalizations in the reader, the novel had to insist on the priority of a single, superior moral criterion for dealing with the problem of slavery: As numerous critics have shown, it is this the power of the heart, of natural emotion and moral sentiment, to penetrate to the perception of a moral order--a sentimental epistemology which also has the effect of putting women in the position of superior moral authority. 
On the whole, this characterization already points to a first tension or dilemma in the novel. On the one hand, the potential national novel has to sentimentalize itself in order to discuss the national disgrace from a truly moral perspective; while the sentimental novel, on the other hand, sociologizes and radicalizes itself in order to embrace questions of national self-definition. It is one explanation for the singular status of Uncle Tom's Cabin in American literary history that the novel must be considered an unusual, hybrid mixture of the social and the moral, of the potential of the historical and social novel linked with the strategies of sentimental fiction.

It may be helpful at this point to contrast this project of a national novel which tries to address a crucial question of American history from the perspective of sentimental fiction with another version of the literary genre which played such a prominent part in the attempts at a national self-definition which dominated the first half of the nineteenth century in the U.S. Under the influence of Scott and starting with the work of Cooper, the historical novel had become one of the dominant genres in the development of American fiction. Designed to account for the historical emergence, social variety and moral quality of a civilization, the genre seemed ideally suited for an examination of the new social order established in America. The guiding question in such books as, for example, Cooper's first Leatherstocking tale The Pioneers, 
clearly is to what extent this social order had already fulfilled the promise of a new and superior stage of civilization associated with the idea of America from its very beginning. In exemplary acts of conversion or rejection, of integration or symbolic expulsion, The Pioneers is therefore trying to use fiction as a testing-ground for the symbolic reconstruction of a new social order in which the social and the moral would finally coalesce. For Cooper, at least the Cooper of The Pioneers, such a reunion can still be confidently envisioned--all that is required in order to effect a moral regeneration is a firm hand in controlling and, where necessary, eliminating the savage elements on the fringes of civilization.

In the hierarchical world of The Pioneers, divided into an upper world of civilizing forces and a nether world of savage elements, slavery does not yet pose a problem; in fact, Cooper does not even seem to be aware of its moral dimension. In contrast, Beecher Stowe sees the central moral problem endangering the promise of a new and morally regenerated American civilization not on its borders, but at the very heart of civilized society itself. If the social fabric is crucially contaminated by slavery, however, then such defect can no longer be regarded as a temporary threat which can be safely entrusted to society's pioneers. What generates and shapes Uncle Tom's Cabin as a novel, in other words, is a fundamental split between the social and the moral order which threatens to undermine American 
civilization. Such a view must have been especially disheartening, since American society had based its self-definition on the prospect of establishing a new stage in the development of human civilization--which included the promise that the social and the moral which had fallen apart in a corrupt old world could be successfully reunited in the New. The growing awareness of the problem of slavery, on the other hand, must have raised the terrible suspicion of a permanent split between the two orders. If something was to be done against this frightful prospect, then it had to be of a sweeping and sufficiently radical nature, transcending the carefully controlled rationality of the customary discussions of the issue. It is in this situation, as Philip Fisher has shown, that Beecher Stowe reappropriated the literary genre which is traditionally concerned with--in fact, seems to be brought into existence by--the conflict between the social and the moral: that of sentimental fiction.

My starting point, then, for the following discussion of Uncle Tom's Cabin is the assumption that sentimental fiction takes its departure from a rupture between the social and moral order which threatens to become permanent. 7 In this it can be seen as reaction to a historical moment in which the reality and superiority of the moral order can no longer be taken for granted and must be recuperated in a gesture of often violent reunification and reaffirmation. Such a view of the sentimental as being 
generated by, among other things, the fear of a permanent split between the social and the moral can help to explain two of its most obvious and enduring features: To start with, sentimental fiction is always constituted by a violation of the moral order, by an often violent separation from one's object of affection. The ensuing task of overcoming this fear of separation by reaffirming the seemingly endangered moral order at all costs, may provide a first suggestion for understanding the often forced and exaggerated nature of the sentimental reconciliation of the moral and the social.

The need for reaffirmation, in turn, draws attention to what I see as the basic problem of narrative representation in the sentimental text. If sentimental fiction wants to respond to the threat of a split between the two realms by reaffirming the reality and superiority of the moral order, then it has to find ways of representing this order in especially convincing and moving ways. Sentimental fiction can thus be regarded as a specific symbolic strategy to make an increasingly elusive order 'visible' again. As the history and changing fortunes of sentimental fiction demonstrate, this has also remained its biggest problem. For since the values which it wants to elevate and represent in fiction are, by definition, immaterial and of a 'merely' spiritual or emotional nature, the sentimental text has to rely on equivalents or analogies (if not allegories) for the moral realm. And this, in turn, 
may provide an explanation for both our positive and negative reactions to sentimentality: On the one hand, the reader may experience the deliberate and emphatic channeling of emotions into an object of social analysis in positive ways, as a kind of recharging of the social world with moral meaning. Wherever he or she is, on the other hand, not convinced by the analogy for fusing the social and the moral, there will be the impression of a forced way of creating meaning.

I I .

The beginning of a novel is usually an especially important and instructive moment for understanding the project that is getting underway. Uncle Tom's Cabin begins with the description of a conversation between Tom's master, the gentleman farmer Shelby, and the slave trader Haley:

Late in the afternoon of a chilly day in February, two gentlemen were sitting alone over their wine, in a well-furnished dining parlor, in the town of P__ in Kentucky. There were no servants present, and the gentlemen, with chairs closely approaching, seemed to be discussing some subject with great earnestness. For convenience sake we have said, hitherto, two gentlemen. One of the parties, however, when critically examined, did not seem, strictly speaking, to come under the species. He was a short, thick-set man, with 
coarse, commonplace features, and that swaggering air of pretension which marks a low man who is trying to elbow his way upward in the world. He was much over-dressed, in a gaudy vest of many colors, a blue neckerchief, bedropped gayly with yellow spots, and arranged with a flaunting tie, quite in keeping with the general air of the man. His hands, large and coarse, were plentifully bedecked with rings; and he wore a heavy gold watch-chain, with a bundle of seals of portentous size. . 8

Two things may be noted for the purposes of our discussion. For once, it is at this point still the authorial voice which is the main source of moral meaning for a reader who is placed in a safe position outside of the book. And secondly, the authorial voice can provide these moral meanings because signs can still be counted upon to represent the moral dimension of reality in a reliable way: the fact that Haley elbowed his way upward in the world and thus obviously violated the moral and social equilibrium (= the image of pushing others aside) is plainly visible in the embarrassing, almost grotesque violations of taste and proportion which characterize his outer appearance. The authorial voice can thus be quite confident that in piling up instances of such disproportion, it will be able to establish a consensus with the reader about the deplorable lack of a moral dimension in Haley's character.9 Ironically enough, however, it is this mode of 
representation, in which linguistic and visual signs do still have a stable moral referent, which also poses the main problem for the novel. This becomes obvious when the two men begin to talk about Tom:

"Why, the fact is, Haley, Tom is an uncommon fellow; he is certainly worth that sum anywhere,-steady, honest, capable, manages my whole farm like a clock."

"You mean honest, as niggers go," said Haley, helping himself to a glass of brandy.

"No; I mean, really, Tom is a good, steady, sensible, pious fellow. He got religion at a camp-meeting, four years ago; and I believe he really did get it. I've trusted him, since then, with everything I have,--money, house, horses,--and let him come and go round the country; and I always found him true and square in everything." (p. 12)

The phrase "you mean honest, as niggers go" draws attention to the problem which Beecher Stowe had to overcome: within the dominant cultural convention, blackness may have held connotations of various possibilities, but not that of genuine morality. While all other signs can, in other words, be relied upon to represent a moral dimension of reality, in the case of the 'black', this moral dimension is suppressed by the cultural semantics of blackness. ${ }^{10}$ What the novel thus has to do, if its 
argument is to be successful, is to transform and resemanticize the meaning of the sign 'black' by moving it, as Yuri Lotman would put it, from one semantic field--which comprises all characters and settings linked by their lack of a genuine moral dimension--to the semantic field informed by genuine morality. Or, to put it differently, the fact that the public meaning of the sign 'black' misrepresents Tom as a person does not lead the novel to a deliberate foregrounding of the tyranny of signs (as would be the case in high modernism and postmodernism), but to a concerted effort to resemanticize this one sign within a cultural system and mode of literary representation which the novel wants to strengthen, not to question in order to achieve its own cultural and political goals. For this goal of a resemantization, however, the comments of the authorial voice alone are obviously not strong enough, at least not for establishing and making visible a version of the moral order by which our feelings could be sufficiently engaged. If Uncle Tom's Cabin would have to rely on the narrator's power of persuasion alone, it would remain a form of mere preaching. The novel has to draw on other narrative devices such as, for example, melodramatic plot patterns, and of these the repositioning of the reader may be the most important and the most effective. Significantly, it is at the moment in which Mr. Shelby confesses that he has sold Tom and Eliza's child, that the novel begins to move away from the Shelbys and, with it, from the gentry world of 
refined and enlightened society members, and begins to take the side of the victim:

There was one listener to this conversation whom Mr. and Mrs. Shelby little suspected.

Communicating with their apartment was a large closet, opening by a door into the outer passage. When Mrs. Shelby had dismissed Eliza for the night, her feverish and excited mind had suggested the idea of this closet; and she had hidden herself there, and, with her ear pressed close against the crack of the door, had lost not a word of the conversation. When the voice died into silence, she rose and crept stealthily away. Pale, shivering, with rigid features and compressed lips, she looked an entirely altered being from the soft and timid creature she had been hitherto. (p. 49 f.)

By shifting, to the perspective of one of the potential victims, the novel manages to transform us from an imaginary participant in a conversation with the authorial voice--and thus from the position of a social equal--to the stance of a helpless onlooker who can only compensate for his or her own helplessness by an intensification of emotional involvement. 11 This is, of course, the basic transformation that the novel wants to achieve in the reader and on which it bases its whole theory of effect. The drama of separation, loss and reunion, is thus repeated on the formal level of the text: sentimental texts want to 
eliminate aesthetic distance, but in order to achieve this, they first have to make us experience such distance as painful.

Yet the skillful narrative evocation of a fear of painful separation must be placed within the larger context of a moral order if it is to be effective. If the reader is to be shocked into an awareness of the vulnerability of the moral order, he or she must also be confronted with an image of that which is threatened; in other words, with versions of an intact order that can serve as a norm and counter-model for the staging of its possible breakup. It is here that sentimentality in the sense of a specific system of cultural values and beliefs comes into play, for it provides Beecher stowe with powerful images for a still successful blending of the social and the moral realm. Significantly, Eliza is not only a woman but a mother; the fear of separation with which the novel begins is caused by the threat of a family breakup. In a typical sequence of events and chapters, the fear of separation created in the first three chapters is thus contrasted with a description of that idyll and institution which is threatened most in the novel, that of home and family. As Philip Fisher has shown convincingly, it is the depiction of the family which provides the main metaphor for a still intact version of social and moral order in Uncle Tom's Cabin--at least at its beginning. This is not, as Fisher rightly asserts, to be understood as a retreat from the realm of the political. On 
the contrary, as long as we insist on seeing it that way, we will overlook the larger political and cultural implication of the move, that of a far-reaching dehierarchization and democratization. 12 For, clearly, what the metaphor of the family does is to redefine a character such as Tom in a new social role: instead of emphasizing his ethnic identity, he is now presented in the roles of father, husband, and especially that of uncle, which establishes, in the very title of the book, a family relation between white and black. In emphasizing social rather than ethnic aspects of identity, a common emotional bond is thus created in order to encourage the reader to invest emotions which would otherwise be held back.

In view of the available options, this is a shrewd and effective strategy of humanization. Other metaphors of the nation--for example that of the ship--inevitably imply functional hierarchies. The family, on the other hand, was reconceptualized in the eighteenth century as the one social group which is held together by an emotional bond and thus entitles each of its members to a just share of solidarity and protection. As Ellen Goodman points out, the "family is formed not for the survival of the fittest, but for that of the weakest"; it is, beginning with the eighteenth century, no longer a primarily economic unit, but an emotional one.13 In consequence, the family emerges in Uncle Tom's Cabin as the most important barrier to a final split between the social and the moral which threatens the nation. Seen 
in this context, the sentimental discourse within the novel must be considered as a strategy by which the segregated black becomes a member of a nation redefined as family, and should thus be treated on the basis of a common emotional and social bond.

Such a strategy, which, for the first time in American history, may have managed to make the black visible as a moral being, was preceded by two similar acts of dehierarchization and democratization. The first wave of sentimental fiction established by Richardson in the eighteenth century can be seen as an attempt to elevate woman to the level of a socially equal and morally superior participant in social life. In the early nineteenth century, this sentimental claim is then further extended to include the figure of the child. And in Uncle Tom's Cabin, Beecher stowe adds another link to this chain, 14 and she does so by linking the figure of the black with that of the child--above all, with that of Little Eva who is a supreme example of all the sentimental idealizations of the child in the nineteenth century. The crucial argument which the novel levels against slavery is therefore not based on primarily political or philosophical considerations. Instead, the novel asserts the priority and necessity of a moral perspective. The most devastating argument against slavery is that it tears apart the one social body in which the social and the moral is still happily united, that of the family. 
If the novel is to be effective in its argument, however, then it has to extend the sentimental chain to include yet another figure as part of the family, namely the reader himself. In a historical novel such as The-Pioneers, the reader is still addressed as a primarily public self who is to be drawn into an ongoing dialogue on the nature and quality of American civilization. In Uncle Tom's Cabin, in contrast, the reader is urged to give priority to the private self and to overcome his or her rational distance in order to join the national family. For only as a person who relies on his or her own feelings and emotional responses as the primary source of knowledge will the reader be able to realize the full moral dimension of what is going on; only if the reader is willing to act and feel toward the victimized characters as if they were his or her own kin, will he or she be able to develop an intense feeling of moral responsibility.

It is within this context of a transformation of the reader that the role and significance of the melodramatic elements of the novel have to be seen. Quite obviously, they are sentimentality's other side of the coin. They provide the necessary dimension of threat and fear of separation--of which death is only the most spectacular and final--which are a necessary precondition for the forceful sentimental reaffirmation of union and togetherness. This function is already apparent in the very first scene of the novel in which our anxieties about the possible breakup of 
the social and moral fabric are evoked skillfully. This first threat of separation, melodramatically staged in the slave trader's offer to buy Eliza's little boy, marks the beginning of an endlessly repeated cycle of painful separations and happy reunions, of unbelievable streaks of misfortune and the most fortunate coincidences, of ever renewed persecution and last-minute escapes. In both Tom's and Eliza's story, experiences of threat, loss, separation, and victimization form the center of the narrative. And in both cases, we can observe a basic interaction between melodramatic threat and sentimental reaffirmation. As a rule, it can be said that the stronger the melodramatic staging of loss, the stronger the sentimental reaffirmation following it. To give but three of the most obvious examples: the climax of Eliza's story and one of the most thrilling scenes of the novel, her hair-breadth escape over the raging fiver on its dangerously drifting pieces of ice, is soon followed by the heavily idealized picture of the major model family of the novel, that of the Quaker household. Similarly, the approaching deaths of Little Eva and Tom seem to increase the deliberately sentimental evocation of a higher link and purpose in their fates. Not accidentally, critics who dislike the novel have focussed on these scenes as the most problematical.

The melodramatic discourse thus plays its own role in the strategy of emotional activation and participation which the novel pursues. It is primarily responsible for 
putting the reader into the position of a family member who is cut off from his or her own relatives, longing for reunion. And this drama gains a special intensity and meaning, I think, because it is designed to act out a terrible suspicion: amid the constantly renewed cycles of misfortunes and unfortunate accidents, the impression must grow that the incessant violations of the moral order are committed without due punishment and proper moral retribution. The melodrama can thus be seen as that discourse in which the moral order has assumed an increasingly enigmatic dimension, and in which its very existence is questioned. The fear that it evokes is that the characters with which the reader sympathises might have been left alone and deserted in a hostile universe. Its deeply disturbing events seem to defy the belief in a benevolent moral order governing our lives.

If all of this is correct, however, if the implied reader of the melodramatic discourse is that of a separated private self shaken by fears of loss, then this melodramatic element can also develop a tendency to work against the very discourse which it is designed to support, the sentimental affirmation of family and togetherness. For, as a rule, the melodrama has an inbuilt tendency to maximize its effects of victimization until the very last minute and thus to delay the moment of reassurance. The sentimental celebration of the idea of the family, on which Beecher stowe bases her strategy, must be interested, on the other hand, in 
providing as many model images of the saving power of the family as possible. This is quite obvious (and works quite well) in the first half of the novel, where an alternating narrative rhythm between the melodramatic disturbance of the family and its sentimental reaffirmation prevails: the threat to Eliza and her family is followed by the description of Tom's idyllic family life; her narrow escape over the river is succeeded by the glowing idealization of the Quaker family. But as the novel progresses and shifts its narrative focus increasingly to the Tom-plotline, the suspicion seems to increase that the family may not be strong enough after all to carry the full burden for a scenario of national regeneration. The two basic elements of the narrative, the melodramatic disturbance of a moral order and its sentimental reaffirmation, are thus in danger of falling further and further apart; which in turn means that if the novel wants to continue to provide effective images of reunion, it has to move to another analogy or, as Jane Tompkíns puts it very fittingly, to another storehouse of commonly held assumptions.

In reaction, a third discourse within the novel becomes stronger and stronger--significantly at a moment in which the description of the family life at the St. Clares sharpens our sensibility that the family as a social body and cultural institution may not be strong enough to provide a real alternative to the social forces which have created and maintained slavery as a social institution. 15 As a 
consequence, Little Eva, who is no longer at home in this earthly family, has to be moved to another, this time transcendent family, the celestial community of saints and innocents. And the problem increases even further as the novel moves on to the perverted, familyless world of the bachelor Legree, where a moral redemption of Tom's terrible fate can only be found in the analogy to the story of Christ. In both cases, that of Little Eva as well as that of Tom, the sentimental affirmation has thus to turn to the level of typological thought, that is, to a method of interpretation which gives moral meaning to characters and events by drawing on analogies to the Bible. At a moment of increasing threat that can no longer be controlled by the up to then prevalent forms of sentimental reaffirmation, the typological discourse provides a new stability to the semantic fields of the novel which have been destabilized by the extended melodramatic discourse; it thus makes it possible once again to know and judge with confidence. Typological references can be found in the novel from the start. One of her (reluctant) black pursuers, for example, relates Eliza's miraculous flight over the river to the crossing of the river Jordan; similarly, the home, for example that of the Quaker family, can be seen as a type of Paradise to come. But such typological references remain dominated in the first part of the novel by the powerful enactment of its many melodramatic plot elements and by the richness of its social and political analysis. In the 
subplot around Eliza people may suffer, but they also find ways to escape and to rebuild their lives. In contrast, Little Eva and Tom become supreme examples of the innocent, defenseless victim for whom Christ's redemption through sacrifice is used as a type. By this strategy, the novel gradually replaces one model of the moral order, that of the family, by another, that of the Bible as the highest authority on questions of moral justice and providence, of guilt and redemption which we have in our Western civilization. In other words, in response to a growing doubt and anxiety about the existence of a moral order, the novel shows an unmistakable tendency to dissolve the sentimental discourse into the typological; or, to put it differently, to stabilize the increasingly difficult sentimental affirmation by reference to a holy text that can serve as supreme evidence of the existence of a moral order. Not surprisingly, it is this level of typological reference with which modern readers have had the greatest difficulties. In fact, I think it is fair to say that for the modern reader the novel becomes increasingly difficult to handle the more it typologizes itself. For while the analogy of the family is still familiar and can be revived and reimbued with meaning, as Fisher's essay has shown, the typological affirmation of a moral order, as Jane Tompkins in turn has shown, is no longer a code on which the modern reader can or wants to draw. 16 (Significantly, the typological dimension of the novel is not even mentioned in 
Fisher's argument.) 17 The gradual disregard of the typological dimension of the novel is already apparent in its immensely popular stage adaptations in the second half of the nineteenth century. What must have been an essential source of the novel's enormous impact and popularity at the time of its publication--its skillful blending of social analysis, melodramatic plot patterns and sentimental affirmation of the family into the all-embracing context of a typological redefinition of the national dilemma, in other words, its extension of national history into eschatological vision--quite obviously poses the main problem for the novel's modern reception. 18

And this, I think, can provide some further insight into the problems with sentimentality which we may have as modern readers. For if sentimental fiction is indeed an attempt to reconcile the social and the moral, if it is, in other words, trying to make something visible that seems to have become increasingly enigmatic, then its success as a cultural strategy does not depend primarily on its rhetorical force, but on the familiarity, plausibility, and cultural authority of the analogies which it introduces for its own purposes of a literary representation of the threatened moral order. The often amazing impact of sentimental fiction can be explained by the fact that it has the courage to foreground those hidden models and metaphors through which we keep our faith, however tenuous it may be, in a form of life that still has a moral structure-- 
metaphors such as the family, the collective, the loving couple. On the other hand, we will hold a strongly negative and maybe even derogative view of sentimentality wherever we have the impression that the text wants to manipulate us into the acknowledgment of a value or metaphor which we are no longer willing to accept as a convincing configuration of union. With the loss of the cultural authority for the models and metaphors on which it bases its confidence in the possibility and power of literary representation, the literary text also loses its power to represent a moral order convincingly. What occurs as a result is a shift between levels of definition: instead of being an emotionally engaging literary representation of a system of cultural beliefs (= definition 1), sentimentality in literature turns into only another case of rhetorical excess (= definition 3 ).

IV.

Such observations can lead back to a reconsideration of sentimental fiction as a mode of literary representation. Fiction can, by definition, be seen as that kind of discourse which tries to express something otherwise 'unnameable' or 'inexpressible'. The story of the changing concepts of this otherwise inaccessible dimension of meaning is also a story of constant retreat: in nineteenth-century organicism, it is still a condensed essence which only great philosophical and artistic works can grasp; in 
twentieth-century formalism, it is the pressure of the artistic form that transforms the semantics of everyday language into a meaning that can no longer be retranslated into other forms of discourse; while in poststructuralism meaning can no longer be grasped even as a somewhat elusive Gestalt configuration, but can only be conceptualized as a constant process of deferral and dissemination. In comparison--and this, I think, lies at the bottom of our contemporary distrust of the sentimental--sentimental fiction promises to do the impossible: it is still insisting on its ability to represent an invisible order in writing by drawing on a certain system of gestures and narrative devices, while modernism as an avant-garde movement has gone exactly in the opposite direction, namely to question the literary representation of authentic values by creating a carefully controlled system of ambiguities and indeterminancies that, at least in theory, would allow the reader to be part of that process of exploration which literature is supposed to initiate.

The aesthetic problem surrounding sentimental fiction would, in this case, not be its lack of rhetorical restraint, but its insistence on an idea of literary representation which disregards our modern awareness of the arbitrariness and inherently supplementary character of the process of signification. As we have seen in our interpretation of Uncle Tom's Cabin, however, sentimental fiction can indirectly acknowledge this inherent instability 
by gradually transforming itself in the process of its own inner narrative eventfulness. And this, in turn, can provide us with an additional explanation for the seemingly irrepressible tendency of the sentimental text to plunge into what the modern reader, as a rule, experiences as 'excessive' representation. This excessive gesture, so all-pervasive on all narrative levels of sentimental fiction, can best be understood, I think, as an attempt to recuperate its own power of representation and thus to counter the fears of a failure or even breakdown of its own project of reuniting the social and the moral. A strange irony is at work here: the more the sentimental text becomes afraid of failing, the more it strains itself; the more it strains itself, however, the more it begins to undermine its own premise that an adequate representation of the moral order is still possible; and the more it undermines itself, the more it can be reappropriated by a postmodern sensibility.

From this perspective, sentimental fiction can be seen as a mode of representation generated by a profound anxiety about its own moral referent, which in turn pressures the text toward a permanent surplus of signification. The sentimental text, however, is not a postmodern text and it would be inappropriate to turn it into one--especially in the case of Uncle Tom's Cabin. Instead, it seems more adequate to say that in our contemporary reception sentimental fiction is distinguished 
by the fact that it occupies something like a middle ground between two possibilities and functions of fiction. On the one hand, the sentimental text tries hard to retain the moral referent which it is trying to represent. In other words, an aspect of the 'real', or, at least, the fiction of it, is maintained which modernism and postmodernism tries to question. And this also means that of all the genres based on the idea of a possibility of representation, the sentimental text may work hardest against a technique of self-reflexive distancing which leaves us emotionally 'flat.' Instead it deliberately and unashamedly invites us to fuel our emotions and desires (for union) by projecting them into a system of signs and images. Since what we experience as rhetoric excess has a tendency to draw our attention to the text's failure of representation, we are, on the other hand, reluctant to accept this fiction of the 'real' as authentic, but remain aware of its fictionality. In our contemporary reception we are thus caught in the middle, or, to be more precise, we are constantly moving between emotional involvement and a mode of ironic distancing (something, by the way, that seems also typical of our contemporary attitude toward the opera). Ironically enough then, it is in this sense of a permanent interaction between stances that seem mutually exclusive, between a constant breakdown of the power of representation into a failure of representation which foregrounds itself, that a sentimental novel such as Uncle Tom's Cabin can gain new power and aesthetic interest. 
To speak of a failure of representation, however, may not appear to be the best way to support a renewed interest in the novel and may irritate those who want to argue for the strength of the book's social analysis. For even though I have tried to distinguish the text from consistently postmodern modes of signification, one may still claim that I have submitted the novel to a kind of indirect 'postmodernization' by pointing out its instability of meaning and the ensuing inner 'eventfulness' of its representation. This instability, however, is confirmed by the very readings, most of them of a revisionist or 'historicist' kind, which want to deny it. The pattern of substitution of a moral referent which we observed in the novel itself is re-enacted by current revisionist criticism; taken together, it too,--and inevitably so--mimics the novel's sequence of substitutions, because the moral referent which the novel is supposed to represent can never be prescribed satisfactorily. On the contrary, it is constantly redefined in terms of the various views of social relevance which can be found in revisionist criticism: in Fisher's reading the moral meaning of the novel is derived from a benign populism developed through the analysis of Cooper's work, while for Tompkins the novel represents an idealized version of female communality which she derives from her reading of the domestic novel. For W. B. Michaels, the novel represents a fear and critique of market relations, whereas Gillian Brown sees it as both a 
representation of domestic values and their utopian rehabilitation through a critique of male hegemony; for this "activist female model Stowe proposes," which marks the "arrival of woman as a revisionary social critic," Cassy becomes the role model.19 Jean Fagan Yellin, on the other hand, who examines the novel from the point of view of Angelika Grimké's feminism, fails to see such a critique and finds the only saving grace in certain similarities between Little Eva's and Grimké's lives which establish Eva as a "budding social activist."20 And while Brown and Yellin emphasize a certain degree of ambivalence in the novel's discussion of domesticity, Elizabeth Ammons celebrates it as a successful affirmation of "matrifocal values." 21 Such a list could be extended. 22

Had the novel managed to represent its model of social and moral order successfully, then this constant substitution of a moral referent would neither be possible nor necessary; in fact, it would have to be considered as a diffusion of the novel's message. Thus, revisionist critical practice, like any other interpretative practice, is made possible by a lack which, on the overt level of argumentation, it tends to deny in its attempt to complement the text with that historical or feminist subtext which would supposedly be able to finally make the novel's process of signification stable and transparent. One may argue, however, that, far from being a shortcoming, it is the very 'failure' of representation which, in a strange paradox 
characteristic of fiction, secures the novel's effectiveness: if the text--as might be the case, for example, if it were exclusively typological--would not leave any space for that ongoing process of imaginary supplementation in which current revisionism, although it may not like to acknowledge this, still partakes, then Uncle Tom's Cabin neither would have been able to affect as many readers as it did, nor would it have been able to become meaningful again for contemporary readers, including those who have recovered important dimensions of its meaning and have therefore added to our understanding of the novel and its cultural impact. 
NOTES

1. I am referring specifically to Philip Fisher, Hard Facts. Setting and Form in the American Novel (New York: Oxford University Press, 1985), 87-127 and Jane Tompkins, Sensational Designs. The Cultural Work of American Fiction 1790-1860 (New York: Oxford University Press, 1985). Another body of revisionist criticism which is not a subject of this study (but is occasionally used for points of comparison) is characterized by a more directly politically oriented approach which focuses on the novel's representation of slavery and, more generally, on issues of class, race, and gender. The recent volume New Essays on Uncle Tom's Cabin, ed. Eric J. Sundquist (New York: Cambridge University Press, 1986) offers a good sample. Since modernism's dismissal focuses on the novel's sentimentality, however, a defense of the novel has to come to terms with its sentimental mode of narration. Most 'activist' readings, I think, fall short on this account (in fact, they see the novel's sentimentality as a source of weakness which stands in the way of "social action" or "radical political change"), while it is one of the merits of the 
interpretations by Fisher and Tompkins that they offer powerful redefinitions.

2. Tompkins, Sensational Designs, 122 .

3. John William Ward, Red, White, and Blue. Men, Books, and Ideas in American Culture (New York: Oxford University Press, 1969), 75 .

4. Such an attempt to describe the novel's sentimentality as a complex phenomenon with its own inner contradictions corresponds to recent attempts of revisionist political readings to acknowledge "disturbing elements in the novel that cannot be explained away" and to illuminate its "complicated and somewhat contradictory powers." See the introduction by Eric Sundquist to New Essays on Uncle Tom's Cabin, 4, 1. The essays throughout this volume, wittingly or unwittingly, point to aspects of the novel with which the contemporary reader has difficulties.

5. In talking about Little Eva, even feminists often cannot suppress a note of sarcasm. Cf. Amy Schrager Lang who says: "Loyal, generous, self-denying and faithful, Eva would if she could grow up to become the exemplary wife and mother. In fact, one proof of the evil of slavery is that it deprives this paragon of 
feminine virtue of the domestic happiness which is her due." "Slavery and Sentimentalism: The Strange Career of Augustine St. Clare," Women's Studies 12 (1986): 40. Similarly, Jean Fagan Yellin seems to indicate some irritation when she says: ". . Stowe's book apotheosizes a juvenile white female who triumphs in heaven. - ." "Doing It Herself: Uncle Tom's Cabin and Woman's Role in the Slavery Crisis," New Essays on Uncle Tom's Cabin, 102 .

6. In discussing the scene of Little Eva's death, for example, Thomas $P$. Joswick speaks of "the excess of conventional props (funereal and linguistic) to i stimulate an excess of feelings." "The Crown Without the Conflict': Religious Values and Moral Reasoning in Uncle Tom's Cabin," Nineteenth-Century Fiction 39 (1984): 254. The purpose in providing these competing definitions of sentimentality is to show how they are related to assumptions about successful or failed representation.

7. In his suggestive essay on "Romance and Real Estate," Walter Been Michaels points out that the (slave) market is one of the social institutions which epitomizes this falling apart of the social and the moral. The American Renaissance Reconsidered, ed. W. B. Michaels and Donald E. Pease (Baltimore: Johns Hopkins University Press, 1985), 156-82. 
8. Harriet Beecher Stowe, Uncle Tom's Cabin; or, Life Among the Lowly (New York: Library of America, 1982), 11. All further references in the text will be to this edition.

9. On the function of the "engaging narrator" in Uncle Tom's Cabin see the excellent discussion by Robyn $R$. Warhol, "Toward a Theory of the Engaging Narrator: Earnest Interventions in Gaskell, Stowe, and Eliot," PMLA 101 (1986): 811-18.

10. On the novel's own ambivalent view of race cf. Eric Sundquist, ibid.

11. On the consequences of this shift for the "engaging narrator" of the novel see Warhol: "The first six chapters, which introduce the characters and their various relations to the institution of slavery, contain no emotionally charged episodes and only three passages of intervention, two of which fit the description of 'engaging' addresses to the reader. The next ten chapters, detailing the traumatic experiences of Tom and Eliza directly after their owners' disastrous decision to sell them, contain at least sixteen interventions, no fewer than eleven of them engaging." Ibid., 816. 
12. In this, Fisher provides a convincing counter-argument to those who take the "ideological failure of the novel" for granted.

13. Goodman has repeatedly commented very perceptively on the tension between individualism and the family in American life. The quotation is taken from an article "A Family Celebration for Individuals," New York Herald Tribune, 28.11.1985.

14. If readers see an ambivalence in this metaphor, it is intended.

15. Several critics have pointed out how "Stowe's presentation of a range of home models--on a scale running from Rachel Halliday's ordered, maternal Quaker home and kitchen down through the disordered chaos of Dinah's kitchen at Marie St. Clare's (which Ophelia must set aright) to the drunken hell of Legree's virtual house of prostitution . .--shows the progressive failure of maternal influence." Sundquist, ibid., 23. The most extended discussion of this motif is provided by Gillian Brown, "Getting in the Kitchen with Dinah: Domestic Politics in Uncle Tom's Cabin," American Quarterly 36 (1984): 503-23. 
16. Unwillingly, Amy Schrager Lang confirms this by saying that in the Legree episode we have no model at all for "positive action against slavery." Ibid., 50. This observation only makes sense, however, if "positive action" is used in a modern secularized and post-typological sense. Cf. in contrast, Tompkins' point that it is exactly the typological dimension of the novel which contains its own "theory of power." (Significantly, the part of Lang's essay which deals with the Legree episode does not even mention Tom's fate and role at that point; similarly Tom plays no role in Gillian Brown's argument who switches over to Cassy instead.) Christianity has a theory of action; however, it is one which is most likely not convincing for those who do not share its premises.

17. The point here is not whether the typological dimension can still be recognized nowadays, but whether it will still be valued and be able to generate metaphors for the moral world which people find convincing.

18. On this point, see also Stephen Railton: "Stowe and her readers united in prizing the ability to see the reality that was not there, whether that was the hand of Providence, maternal sovereignty, or Litte Eva. They read this passage and saw someone, but only because they had agreed beforehand on the meaning and 
validity of these terms. We read this passage, and all we can see is the pattern of pieties by which they understood reality." "Mothers, Husbands, and Uncle Tom," Georgia Review 38:1 (1984): 137 .

19. W. B. Michaels, ibid.; G. Brown, ibid., $515 f$.

20. Yellin, ibid., 102 .

21. Elizabeth Ammons, "Stowe's Dream of the Mother-Savior: Uncle Tom's Cabin and American Women Writers Before the 1920s," New Essays on Uncle Tom's Cabin, 155-95.

22. Even where the novel is discussed as 'ideological failure,' the point remains valid, because for critics who criticize the novel on ideological grounds it is not the problem of representation which constitutes the novel's 'failure,' but the fact that the wrong values are represented. 